\title{
Effects of mild hypothermia on hemodynamics in cardiac arrest survivors and isolated failing human myocardium
}

\author{
Claudius Jacobshagen - Theresa Pelster • Anja Pax • Wiebke Horn • \\ Stephan Schmidt-Schweda • Bernhard W. Unsöld · Tim Seidler • \\ Stephan Wagner • Gerd Hasenfuss · Lars S. Maier
}

Received: 13 October 2009/Accepted: 11 January 2010/Published online: 4 February 2010

(C) The Author(s) 2010. This article is published with open access at Springerlink.com

\begin{abstract}
Post-cardiac arrest myocardial dysfunction is a common phenomenon after return of spontaneous circulation (ROSC) and contributes to hemodynamic instability and low survival rates after cardiac arrest. Mild hypothermia for $24 \mathrm{~h}$ after ROSC has been shown to significantly improve neurologic recovery and survival rates. In the present study we investigate the influence of therapeutic hypothermia on hemodynamic parameters in resuscitated patients and on contractility in failing human myocardium. We analyzed hemodynamic data from 200 cardiac arrest survivors during the hypothermia period. The initial LVEF was $32.6 \pm 1.2 \%$ indicating a significantly impaired LV function. During hypothermia induction, the infusion rate of epinephrine could be significantly reduced from $9.1 \pm$ $1.3 \mu \mathrm{g} / \mathrm{min}$ [arrival intensive care unit (ICU) $35.4^{\circ} \mathrm{C}$ ] to $4.6 \pm 1.0 \mu \mathrm{g} / \mathrm{min}\left(34^{\circ} \mathrm{C}\right)$ and $2.8 \pm 0.5 \mu \mathrm{g} / \mathrm{min}\left(33^{\circ} \mathrm{C}\right)$. The dobutamine and norepinephrine application rates were not changed significantly. The mean arterial blood pressure remained stable. The mean heart rate significantly decreased from $91.8 \pm 1.7 \mathrm{bpm}$ (arrival ICU) to $77.3 \pm$ $1.5 \mathrm{bpm}\left(34^{\circ} \mathrm{C}\right)$ and $70.3 \pm 1.4 \mathrm{bpm}\left(33^{\circ} \mathrm{C}\right)$. In vitro we investigated the effect of hypothermia on isolated ventricular muscle strips from explanted failing human hearts. With decreasing temperature, the contractility increased to
\end{abstract}

Electronic supplementary material The online version of this article (doi:10.1007/s00392-010-0113-2) contains supplementary material, which is available to authorized users.

C. Jacobshagen $(\bowtie) \cdot$ T. Pelster · A. Pax · W. Horn ·

S. Schmidt-Schweda · B. W. Unsöld · T. Seidler · S. Wagner ·

G. Hasenfuss - L. S. Maier

Department of Cardiology und Pneumology, Heart Center,

Georg-August-University, Robert-Koch-Strasse 40,

37075 Göttingen, Germany

e-mail: jacobshagen@med.uni-goettingen.de a maximum of $168 \pm 23 \%$ at $27^{\circ} \mathrm{C}(n=16, P<0.05)$. Positive inotropic response to hypothermia was accompanied by moderately increased rapid cooling contractures as a measure of sarcoplasmic reticulum (SR) $\mathrm{Ca}^{2+}$ content, but can be elicited even when the $\mathrm{SR} \mathrm{Ca}^{2+}$ release is blocked in the presence of ryanodine. Contraction and relaxation kinetics are prolonged with hypothermia, indicating increased $\mathrm{Ca}^{2+}$ sensitivity as the main mechanism responsible for inotropy. In conclusion, mild hypothermia stabilizes hemodynamics in cardiac arrest survivors which might contribute to improved survival rates in these patients. Mechanistically, we demonstrate that hypothermia improves contractility in failing human myocardium most likely by increasing $\mathrm{Ca}^{2+}$-sensitivity.

Keywords Hypothermia - Cardiac arrest - Resuscitation · Hemodynamic function - Contractility

\section{Introduction}

Survival after cardiac arrest remains low worldwide, averaging $\leq 6 \%$ for out-of-hospital $[1,2]$ and $18 \%$ for in-hospital arrest [1-3]. Even after return of spontaneous circulation (ROSC) the overall prognosis is poor. The National Registry of Cardiopulmonary Resuscitation (NRCPR) reported in 2006 that among 19,819 adults who regained ROSC, in-hospital mortality was $67 \%$ [4]. One important contributor to the low survival rates after ROSC is post-cardiac arrest myocardial dysfunction that is well described in both animal and human studies [5-9]. Mild hypothermia is the only therapy applied in the post-cardiac arrest setting that has been shown to significantly improve survival rates $[10,11]$. Therefore, international guidelines recommend the induction of therapeutic hypothermia 
(32-34 ${ }^{\circ} \mathrm{C}$ for $12-24 \mathrm{~h}$ ) in all comatose survivors of cardiac arrest $[12,13]$. Several techniques are available to easily and safely induce therapeutic hypothermia [10, 12, 14, 15]. By reducing oxygen consumption and numerous deleterious biochemical and physical mechanisms that lead to reperfusion cell damage hypothermia reduces brain injury and improves neurologic recovery [10, 15]. Moreover, in several animal species [16-19] and nonfailing human myocardium [16] hypothermia has been shown to directly increase cardiac contractility. Contradictory, it has been reported that hypothermia could decrease cardiac output and increase the requirement of inotropics $[15,20]$.

In the present study, we systematically analyzed hemodynamic parameters of cardiac arrest survivors during the hypothermia period. Mechanistically, we investigated the effects of hypothermia on contractility and $\mathrm{Ca}^{2+}$ handling in isolated ventricular muscle strips from explanted failing human hearts in vitro.

\section{Methods}

\section{Clinical data analysis}

We retrospectively analyzed the data from cardiac arrest patients that were consecutively admitted to the Cardiology Intensive Care Unit (ICU) of the University Heart Center of Gottingen between January 2005 and December 2008 and treated with mild hypothermia $\left(32-34^{\circ} \mathrm{C}\right)$. Patients were included when their records were available and all study relevant data were documented. 224 patients were screened. 24 patients were excluded because of missing a significant amount of data. Cardiac arrest was defined as being unconscious as a result of a sudden pulseless collapse; ROSC was a return of a spontaneous palpable pulse. Except for trauma, all causes of cardiac arrest were considered [21-23]. Out-of-hospital as well as in-hospital cardiac arrest patients were included. Patients were eligible if they were 18 years and older. All patients received intensive care interventions as recommended by ILCOR $[12,13]$. The trachea was intubated and central venous access was established in all patients. Invasive blood pressure, heart rate (HR) and pulse oximetry data were monitored continuously. Core temperature was measured continuously by a bladder temperature probe (Foley catheter). Hemodynamic support with inotropic agents or vasopressors was used as indicated to reach a mean arterial blood pressure (MAP) of $80 \mathrm{mmHg}$. The dose of the different catecholamines (epinephrine, norepinephrine and dobutamine) was adjusted according to the clinical judgment of the physician on duty, considering MAP, HR, echocardiography results, urine production and underlying disease. Invasive measurements by pulmonary-artery catheter were performed only in some patients, if the hemodynamic situation deteriorated over time.

If indicated, mechanical devices (intraaortic balloon pump or microaxial LV-assist device [24-26]) were implanted in the cath lab before the patients were transferred to the ICU. Arterial blood gas values were frequently obtained to adjust the ventilator to maintain an arterial oxygen saturation of $94-96 \%$ and a partial pressure of arterial carbon dioxide $\left(\mathrm{PaCO}_{2}\right)$ of $40 \mathrm{mmHg}$ (corrected for temperature). Left ventricular systolic function was assessed by echocardiography in biplane standard views. Hypothermia was induced in all patients that remained unconscious after ROSC. After an initial evaluation of neurological status, all patients received intravenous sedation (midazolam or propofol and fentanyl or sufentanil). To prevent shivering, paralysis was induced by intravenous administration of pancuronium. All patients were cooled with external cool packs and cold infusions, starting right after arrival in the emergency room. In addition, 38 patients received an intravascular cooling catheter (CoolGuard $^{\circledR}$, Alsius) and 28 patients were placed in a cooling tent (DeltaTherm $\left.{ }^{\circledR}, \mathrm{KCI}\right)$. Cooling catheter and cooling tent were implemented when the patients arrived at the ICU. Hypothermia induction was continued during diagnostic or therapeutic procedures such as percutaneous coronary intervention (PCI) or computed tomography (CT) scan. The target temperature of $33^{\circ} \mathrm{C}$ was maintained for $24 \mathrm{~h}$ while the patient continued to be sedated and paralyzed. After $24 \mathrm{~h}$ the patient was rewarmed passively and cautiously $\left(\leq 0.25^{\circ} \mathrm{C} / \mathrm{h}\right)$. Sedation was stopped at a core temperature of $35^{\circ} \mathrm{C}$.

We systematically reviewed the patients' records with respect to baseline characteristics, body core temperature, hemodynamic parameters, hemodynamic interventions, echocardiography results and timings of post-cardiac arrest procedures. Since patients' weight is often unknown in the post-cardiac setting catecholamine doses are presented as $\mu \mathrm{g} / \mathrm{min}$ at certain time points.

In vitro experiments in isolated failing human myocardium

Experiments were performed in ventricular myocardium from human hearts obtained from patients with end-stage heart failure undergoing heart transplantation. The study protocol was reviewed and approved by the ethical committee and were in accordance with institutional guidelines. Preparation of muscle strips was performed as described previously $[27,28]$. Briefly, immediately after explantation of the hearts, the ventricles were stored in cooled, modified Krebs-Henseleit buffer (KHB) that contained (in mmol/L): $\mathrm{Na}^{+} 152, \mathrm{~K}^{+} 3.6, \mathrm{Cl}^{-} 135$, 
$\mathrm{HCO}_{3}{ }^{-} 25, \mathrm{Mg}^{2+} 0.6, \mathrm{H}_{2} \mathrm{PO}_{4}{ }^{-} 1.3, \mathrm{SO}_{4}{ }^{2-} 0.6, \mathrm{Ca}^{2+}$ 2.5, glucose 11.2 , and insulin $10 \mathrm{IU} / \mathrm{L}$. The KHB was continuously bubbled with carbogen $\left(95 \% \quad \mathrm{O}_{2} / 5 \% \mathrm{CO}_{2}\right)$ to adjust the $\mathrm{pH}$ to 7.4 . In addition, the KHB contained $30 \mathrm{mmol} / \mathrm{L}$ 2,3-butanedione monoxime (BDM) to protect the myocardium during transportation and from injury as a result of cutting at the time of muscle strip dissection [29]. Thin ventricular trabeculae (diameter $<0.6 \mathrm{~mm}$ ) were dissected with the help of a stereoscopic microscope. All preparation steps were carried out in the cardioprotective BDM solution. For the mechanical measurements, the muscle strips were transferred to an organ chamber and connected to the force gauge by using fine steel hooks (F30 type 372, Hugo Sachs Elektronik). The muscle strips were submerged in the modified KHB (composition given above) without BDM at $37^{\circ} \mathrm{C}$. Isometric twitches were evoked by electrical stimulation with a stimulation frequency of $1 \mathrm{~Hz}$ (stimulation voltage $25 \%$ above threshold). The muscle strips were initially pre-stretched with $1 \mathrm{mN}$ and allowed to equilibrate for $30 \mathrm{~min}$. Thereafter, the muscle strips were gradually stretched until maximum steady-state twitch force was reached $\left(L_{\max }\right)$. To investigate $\mathrm{SR} \mathrm{Ca}^{2+}$ content, rapid cooling contractures (RCCs) were elicited at steady-state conditions as previously described [27]. On cooling from 37 to $1^{\circ} \mathrm{C}$, all $\mathrm{Ca}^{2+}$ from the $\mathrm{SR}$ is released, which leads to a stable contracture of the muscles, because all $\mathrm{Ca}^{2+}$ transport systems are blocked by the low temperature. The amplitude of the contracture reflects the SR $\mathrm{Ca}^{2+}$ content. Twitch force and RCCs were measured at temperatures of $37,35,33,31$ and $27^{\circ} \mathrm{C}$ under steady-state conditions at a stimulation frequency of $1 \mathrm{~Hz}$. It is important to note that RCCs are contractures induced by an acute rapid temperature jump to $1^{\circ} \mathrm{C}$ and are used as a semiquantitative index of SR $\mathrm{Ca}^{2+}$ availability. These RCCs should not be confused with increase in stimulated twitch tension that is brought by less dramatic changes in steady-state temperature $\left(37-27^{\circ} \mathrm{C}\right)$.

To further investigate the role of the SR in the contribution to the inotropic effect of hypothermia, we used a protocol in which $\mathrm{SR} \mathrm{Ca}^{2+}$ storage function was completely blocked by ryanodine $(1 \mu \mathrm{mol} / \mathrm{L})$ added to the perfusate [17]. RCCs were again performed to check the effectiveness of this protocol. Approximately $20 \mathrm{~min}$ after application of ryanodine force stabilized on a new baseline that was characterized by decreased developed force, increased diastolic force, and prolonged twitch-timing. The absence of any RCCs confirmed a complete blockage of SR $\mathrm{Ca}^{2+}$ handling. Hypothermia was applied again, and the inotropic response was recorded under blocked $\mathrm{SR} \mathrm{Ca}^{2+}$ storage function. Due to the length of the experimental protocols all experiments where run-down corrected for each muscle strip and presented as percentage (\%) of change in force of contraction.

\section{Statistical analysis}

All values are presented as mean \pm SEM. Differences between values were evaluated for statistical significance by use of ANOVA followed by Tukey's post test analysis. Correlations were examined by linear regression analysis. The significance level was set at $P<0.05$.

The authors had full access to and take full responsibility for the integrity of the data. All authors have read and agreed to the manuscript as written.

\section{Results}

Baseline characteristics of the patients

We retrospectively analyzed the data of 200 consecutive cardiac arrest patients between January 2005 and December 2008. The average age of the enrolled patients was $64.5 \pm 1.0$ years (range 18-100 years). $76 \%$ of the cases were out-of hospital arrests. Most patients presented with ventricular fibrillation $(53.5 \%)$ as the initial cardiac rhythm; $34 \%$ of the patients had asystole, 9\% PEA. The predominant cause of cardiac arrest was acute myocardial infarction $(46.5 \%)$ followed by primary arrhythmias in patients with ischemic heart disease $(13.5 \%)$ or other cardiomyopathies (14\%). A significantly reduced systolic left ventricular function (LV) with an initial ejection fraction (EF) of $32.6 \pm 1.2 \%$ (range 10-65\%) was documented by echocardiography. In 75 patients $(38 \%)$ an intraaortic balloon pump was implanted. 6 patients $(3 \%)$ received a microaxial LV-assist device. In-hospital mortality was $45.5 \%$. The detailed baseline characteristics are presented in Table 1.

\section{Cooling and hemodynamic data}

The average time interval from admission to our hospital to ICU arrival was $112.6 \pm 10.0 \mathrm{~min}$ (Table 2). The main reasons for this delay were procedures such as diagnostic coronary angiography (59\%), PCI $(40 \%)$ or CT scans $(11 \%)$. Since cooling was started in the emergency room (ER) and continued during the interventions such as PCI, the initial core temperature (bladder temperature probe) on ICU arrival was already $35.4 \pm 0.1^{\circ} \mathrm{C}$. Body temperatures of 34 and $33^{\circ} \mathrm{C}$ were achieved $4.1 \pm 0.3$ and $7.1 \pm 0.5 \mathrm{~h}$ after admission to the ICU, respectively.

During induction of therapeutic hypothermia, the hemodynamic support by epinephrine infusion could be reduced from $9.1 \pm 1.3 \mu \mathrm{g} / \mathrm{min}$ (arrival ICU) to $4.6 \pm$ 
Table 1 Baseline characteristics

\begin{tabular}{ll}
\hline Total no. of patients & 200 \\
Male sex, no. (\%) & $149(74.5)$ \\
Female sex, no. (\%) & $51(25.5)$ \\
Age, years & $64.5 \pm 1.0$ \\
Out-of-hospital arrest, no. (\%) & $151(75.5)$ \\
Initial cardiac rhythm & \\
Ventricular fibrillation or tachycardia, no. (\%) & $107(53.5)$ \\
Asystole, no. (\%) & $68(34)$ \\
Pulseless electrical activity, no. (\%) & $18(9)$ \\
Not reported, no. (\%) & $7(3.5)$ \\
Diagnosis or cause of cardiac arrest & \\
Myocardial infarction, no. (\%) & $93(46.5)$ \\
Primary arrhythmia (CAD and reduced EF), no. (\%) & $27(13.5)$ \\
Primary arrhythmia (other cardiomyopathy), no. (\%) & $28(14)$ \\
Pulmonary embolism, no. (\%) & $9(4.5)$ \\
Other, no. (\%) & $43(21.5)$ \\
Initial LV ejection fraction, \% & $32.6 \pm 1.2$
\end{tabular}

no number, $L V$ left ventricular, $C A D$ coronary artery disease, $E F$ ejection fraction

Table 2 Cooling parameters

Time interval from ER admission to arrival ICU, min $112.6 \pm 10.0$ Reason for delay

\section{Coronary angiography, no. (\%)}

$118(59)$

Percutaneous coronary intervention (PCI), no. (\%) 79 (40)

CT scan, no. (\%)

Echocardiography, no. (\%)

$64(32)$

Initial body temperature at arrival $\mathrm{ICU},{ }^{\circ} \mathrm{C}$

$35.4 \pm 0.1$

Time interval from arrival ICU to target temperature
To $34^{\circ} \mathrm{C}, \mathrm{h}$
$4.1 \pm 0.3$
To $33^{\circ} \mathrm{C}, \mathrm{h}$
$7.1 \pm 0.5$

$E R$ emergency room, $I C U$ intensive care unit, no number, $C T$ computer tomography

$1.0 \mu \mathrm{g} / \mathrm{min}\left(34^{\circ} \mathrm{C}, P<0.05\right)$ and $2.8 \pm 0.5 \mu \mathrm{g} / \mathrm{min}\left(33^{\circ} \mathrm{C}\right.$, $P<0.05$, Fig. 1a). At the same time, the application rate of the vasoconstrictor norepinephrine did not significantly change (arrival ICU: $5.3 \pm 1.0 \mu \mathrm{g} / \mathrm{min}, \quad 34^{\circ} \mathrm{C}$ : $7.1 \pm$ $0.9 \mu \mathrm{g} / \mathrm{min}, 33^{\circ} \mathrm{C}: 7.5 \pm 0.9 \mu \mathrm{g} / \mathrm{min}, P=0.16$, Fig. $\left.1 \mathrm{~b}\right)$. The infusion rate of dobutamine was not changed (arrival ICU: $0.3 \pm 0.1 \mathrm{~mL} / \mathrm{h} ; 34^{\circ} \mathrm{C}: 0.4 \pm 0.1 \mathrm{~mL} / \mathrm{h} ; 33^{\circ} \mathrm{C}: 0.5 \pm$ $0.1 \mathrm{~mL} / \mathrm{h} ; P=0.23$, Fig. 1c). Despite reduced epinephrine dosage, the MAP remained stable at $82.7 \pm 1.6 \mathrm{mmHg}$ (arrival ICU), $80.7 \pm 1.2 \mathrm{mmHg}\left(34^{\circ} \mathrm{C}\right)$ and $78.4 \pm$ $1.2 \mathrm{mmHg}\left(33^{\circ} \mathrm{C}, P=0.09\right.$, Fig. $\left.2 \mathrm{a}\right)$. The mean $\mathrm{HR}$ significantly decreased from $91.8 \pm 1.7 \mathrm{bpm}$ (arrival ICU) to $77.3 \pm 1.5 \mathrm{bpm}\left(34^{\circ} \mathrm{C}, P<0.05\right)$ and $70.3 \pm 1.4 \mathrm{bpm}$ $\left(33^{\circ} \mathrm{C}, P<0.05\right.$, Fig. $\left.2 \mathrm{~b}\right)$.

During the hypothermia maintenance period $(24 \mathrm{~h}$ at $33^{\circ} \mathrm{C}$ ) the catecholamine dosages were not changed
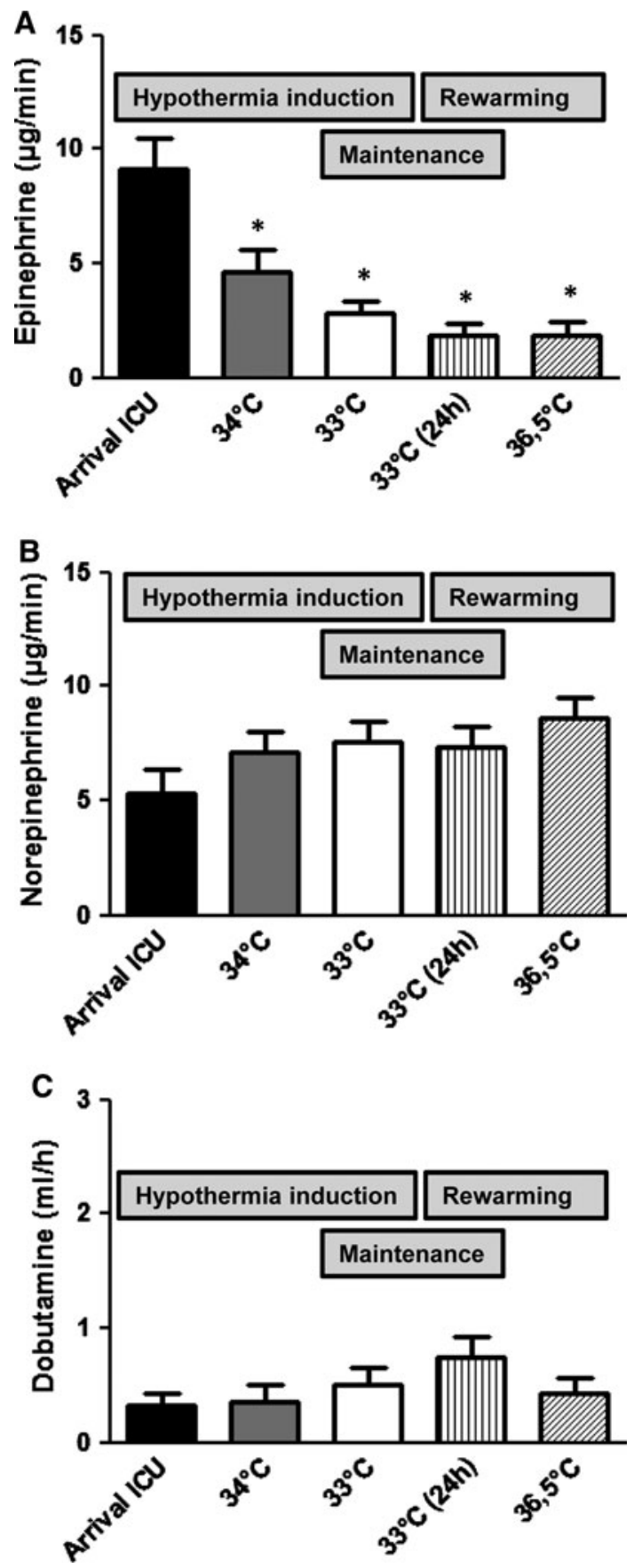

Fig. 1 Hemodynamic support by catecholamines during induction of therapeutic hypothermia (on arrival at the intensive care unit $(I C U)$, at 34 and $33^{\circ} \mathrm{C}$ body temperature) and during the re-warming period (after $24 \mathrm{~h}$ at $33^{\circ} \mathrm{C}$ and after reaching $36.5^{\circ} \mathrm{C}$ ): a infusion rate of epinephrine. $* P<0.05$ versus arrival ICU. b Infusion rate of norepinephrine. $\mathbf{c}$ Infusion rate of dobutamine

significantly (Fig. 1). During re-warming, the infusion rate of norepinephrine slightly increased $(P=0.16)$, whereas epinephrine and dobutamine remained stable (Fig. 1). 

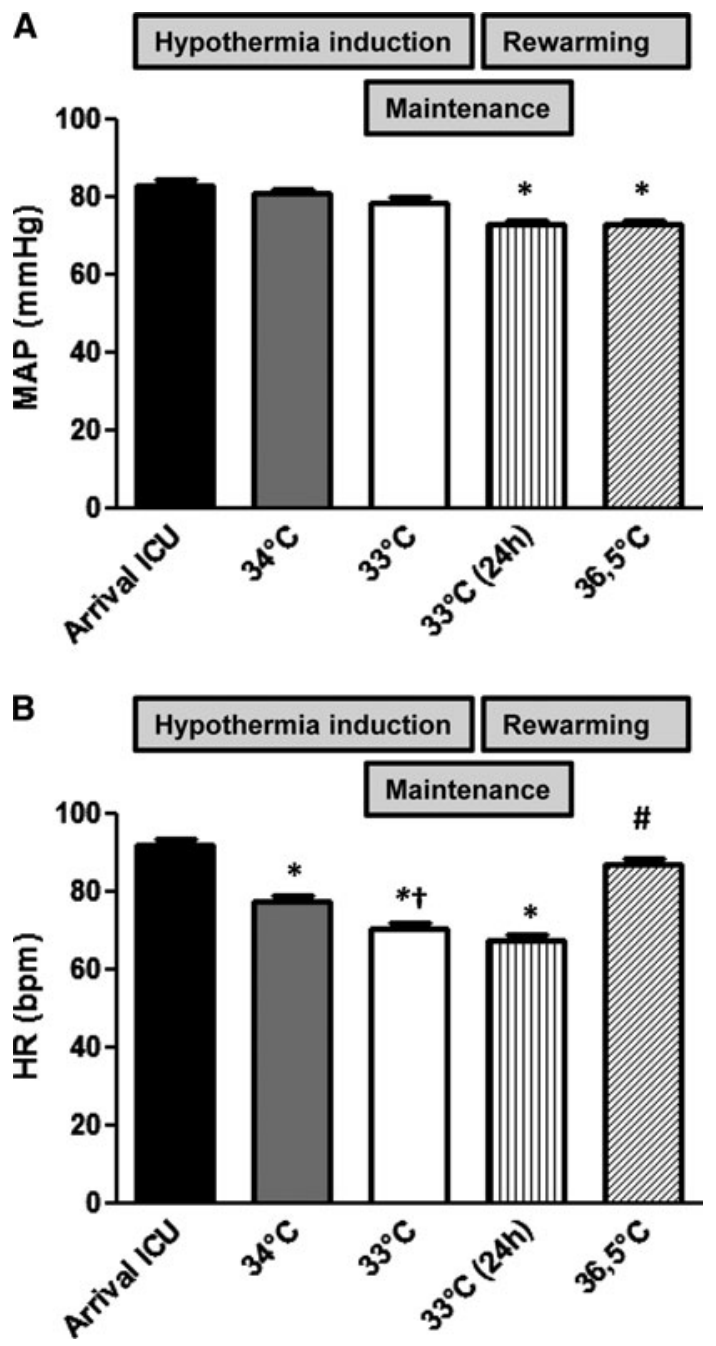

Fig. 2 Hemodynamic parameters during induction of therapeutic hypothermia (on arrival at the intensive care unit $(I C U)$, at 34 and $33^{\circ} \mathrm{C}$ body temperature) and re-warming (after $24 \mathrm{~h}$ at $33^{\circ} \mathrm{C}$ and after reaching $36.5^{\circ} \mathrm{C}$ ). a $M A P$ mean arterial blood pressure. $* P<0.05$ versus arrival $\mathrm{ICU}, 34$ and $33^{\circ} \mathrm{C}$. b $H R$ heart rate. $* P<0.05$ versus arrival ICU, ${ }^{\dagger} P<0.05$ versus $34^{\circ} \mathrm{C},{ }^{\#} P<0.05$ versus 34,33 and $33^{\circ} \mathrm{C}(24 \mathrm{~h})$

$40 \%$ of the patients were treated with PCI before they were transferred to the ICU. To exclude the hemodynamic effect of myocardial recovery due to PCI we analyzed the data of all patients not treated with PCI. The results in this subgroup did not differ from the whole study population (Figs. 5, 6, online data supplement).

The efficacy of catecholamines can be impaired by acidosis. Therefore, we analyzed the arterial $\mathrm{pH}$ values during hypothermia induction. At arrival to the ICU the $\mathrm{pH}$ value was $7.30 \pm 0.01$, indicating a mild acidosis. With hypothermia induction the $\mathrm{pH}$ increased to $7.39 \pm 0.01$ at $34^{\circ} \mathrm{C}$ and $7.40 \pm 0.01$ at $33^{\circ} \mathrm{C}(P<0.05$ vs. arrival ICU, Fig. 7, online data supplement).
Effect of hypothermia on contractility of isolated failing human myocardium

Ventricular myocardium from human hearts was obtained from 15 patients with end-stage failing dilated $(n=6)$ or ischemic ( $n=9$ ) cardiomyopathy undergoing heart transplantation. Mean age of the patients was $55.5 \pm 2.2$ years, and mean EF was $23.5 \pm 1.7 \%$; 5 patients were women. Detailed clinical data of these patients including medications are shown in Table 3 (online data supplement).

In failing human myocardium hypothermia induced a temperature-dependent increase in force of contraction, reaching statistical significance at $33^{\circ} \mathrm{C}$ and lower. Figure $3 \mathrm{a}$ demonstrates that a stepwise reduction in bath temperature from 37 to $27^{\circ} \mathrm{C}$ resulted in a maximal increase in force of contraction to $167.5 \pm 23.0 \%$ $\left(P<0.05\right.$ vs. $\left.37^{\circ} \mathrm{C}, n=16\right)$.

To further elucidate the subcellular mechanism of the inotropic effect of hypothermia, RCC experiments were performed. By cooling the myocardium rapidly to $1^{\circ} \mathrm{C}$, all $\mathrm{SR} \mathrm{Ca}^{2+}$ is released leading to a stable contracture that is indicative of the $\mathrm{SR} \mathrm{Ca}^{2+}$ content. By step wisely lowering the baseline temperature from 37 to $27^{\circ} \mathrm{C}$ RCC amplitudes increased to a maximum of $145.2 \pm 8.4 \%$ at $27^{\circ} \mathrm{C}$ $\left(P<0.05\right.$ vs. $37^{\circ} \mathrm{C}, n=16$, Fig. $\left.3 \mathrm{~b}\right)$. This suggests that hypothermia increases $\mathrm{SR} \mathrm{Ca}^{2+}$ content in failing human myocardium.

To further investigate the contribution of the SR to the inotropic effects of hypothermia, SR function was inhibited by ryanodine. Under SR blockade hypothermia still increases contraction force amplitudes, reaching $145.1 \pm 13.6 \%$ at $31^{\circ} \mathrm{C}(P<0.05, n=13$, data not shown). Interestingly, at $27^{\circ} \mathrm{C}$ the contraction force amplitude slightly decreased to $93.9 \pm 17.0 \%(n=13)$. This is caused by a pronounced increase of the diastolic force at $27^{\circ} \mathrm{C}$, exceeding the increase in systolic force (Fig. 3c). However, in the temperature range from 37 to $31^{\circ} \mathrm{C}$ the inotropic response to hypothermia was still observed after blockade of SR function with ryanodine. A linear regression analysis reveals that - excluding the $27^{\circ} \mathrm{C}$ values - there is a linear correlation between the contraction force with and without ryanodine $(r=0.75$, $r^{2}=0.57$, Fig. $3 \mathrm{~d}$ ) between 37 and $31^{\circ} \mathrm{C}$. This indicates that the SR is not the main contributor to the positive inotropic effect of hypothermia.

Figure 4 demonstrates the influence of hypothermia on contraction and relaxation kinetics. The positive inotropic effect of hypothermia is associated with a significant increase in time to peak tension (TTP), total twitch time (TTT) and time to 50 and $90 \%$ relaxation (RT 50 and RT 90) typical for an increase in myofilament $\mathrm{Ca}^{2+}$ sensitivity. This prolongation in contraction and relaxation times was even more pronounced in the presence of ryanodine. 
Fig. 3 Effect of hypothermia on contractility and $\mathrm{Ca}^{2+}$ handling in isolated muscle strips from failing human myocardium. a Change in force of contraction during stepwise cooling from 37 to $27^{\circ} \mathrm{C}$. Stimulation frequency: $1 \mathrm{~Hz}$. Average values from 16 muscle strips given in percent of the control value at $37^{\circ} \mathrm{C}$. ${ }^{*} P<0.05$ versus control $\left(37^{\circ} \mathrm{C}\right)$. b Influence of temperature on rapid cooling contractures $(R C C)$. Changes in the amplitude of RCCs upon cooling are given in percent of the control value at $37^{\circ} \mathrm{C}$. Average values from 16 muscle strips. ${ }^{*} P<0.05$ versus control $\left(37^{\circ} \mathrm{C}\right) . \mathbf{c}$ Effect of ryanodine on systolic and diastolic force during mild hypothermia. Average values from 13 muscle strips. ${ }^{*} P<0.05$ versus control $\left(37^{\circ} \mathrm{C}\right)$. d Correlation of change in force of contraction during hypothermia with and without ryanodine. $27^{\circ} \mathrm{C}$ values were excluded since diastolic force increased excessively at $27^{\circ} \mathrm{C}$. Scatter plot with linear regression analysis and $95 \%$ confidence interval. $r=0.75$, $r^{2}=0.57$
A
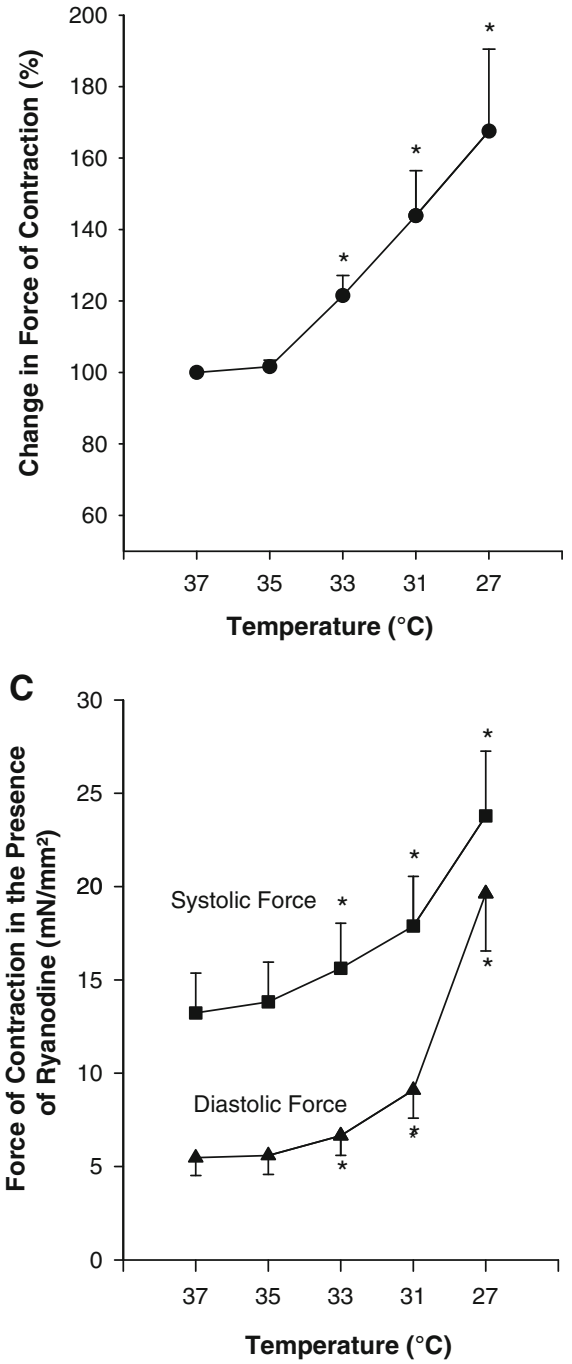

B

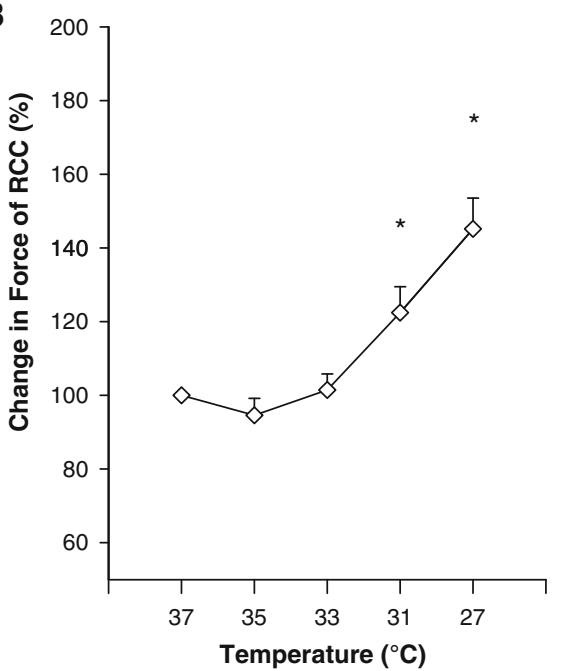

D

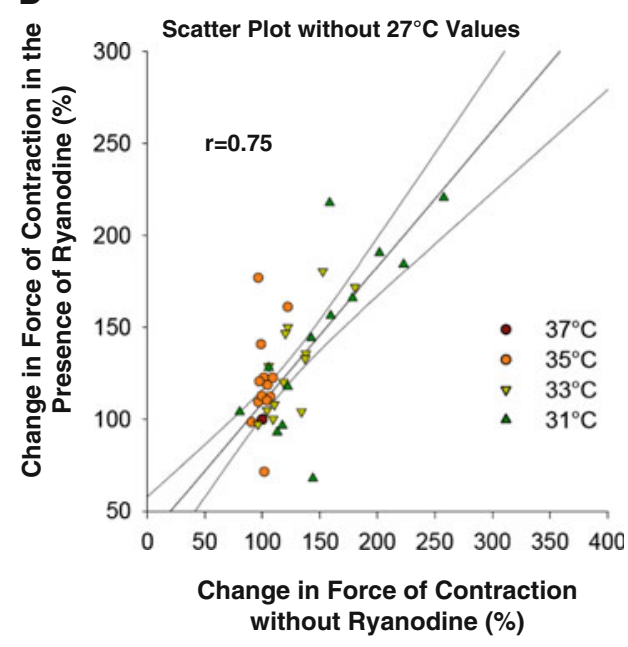

\section{Discussion}

The present study demonstrates that mild hypothermia improves hemodynamics in cardiac arrest survivors. In isolated failing human myocardium hypothermia significantly increases contractility. Positive inotropic response to hypothermia is accompanied by moderately increased SR $\mathrm{Ca}^{2+}$ content but can be elicited even when the SR $\mathrm{Ca}^{2+}$ storage function is blocked. Contraction and relaxation kinetics are prolonged with hypothermia, indicating increased $\mathrm{Ca}^{2+}$ sensitivity of the myofilaments as the main mechanism for inotropy.

Hypothermic inotropism has been shown previously in several animal studies [16-19]. In 1897, Langendorff [18] was the first to describe a relation between temperature and myocardial function. Moreover, hypothermia has been shown to increase contractility in nonfailing human myocardium [16]. However, in the failing human heart, $\mathrm{Ca}^{2+}$ cycling, contractile function and their response to external interventions are significantly altered compared to nonfailing hearts $[27,30,31]$. Intriguingly, we now demonstrate that mild hypothermia improves contractility also in failing human myocardium. Furthermore, in cardiac arrest survivors presenting with impaired LV function, induction of therapeutic hypothermia was associated with significantly reduced epinephrine requirement indicating hemodynamic stabilization. Since the arterial $\mathrm{pH}$ increased from 7.30 (arrival ICU) to $7.39\left(34^{\circ} \mathrm{C}\right)$, it cannot be excluded that the $\mathrm{pH}$ shift contributes to the reduced epinephrine requirement. However, a $\mathrm{pH}$ of 7.30 indicates a very mild acidosis and by reducing the body temperature from 34 to $33^{\circ} \mathrm{C}$ the $\mathrm{pH}$ is not affected whereas the epinephrine dose could be further reduced from 4.6 to $2.8 \mu \mathrm{g} / \mathrm{min}$.

In the study of Bernard et al. [15] the cardiac index (CI) decreased in hypothermia versus normothermia treated cardiac arrest patients. However, systemic vascular 
Fig. 4 Influence of hypothermia on contraction and relaxation kinetics. Average values from 13 muscle strips with and 16 muscle strips without ryanodine (Rya). Stimulation frequency: $1 \mathrm{~Hz}$. $* P<0.05$ versus control $\left(37^{\circ} \mathrm{C}\right) .{ }^{\#} P<0.05$ with ryanodine versus without ryanodine $\left(37^{\circ} \mathrm{C}\right)$. a Time to peak tension $(T T P)$, b total twitch time (TTT), c time to $50 \%$ relaxation $(R T 50)$, d time to $90 \%$ relaxation ( $R T$ 90)
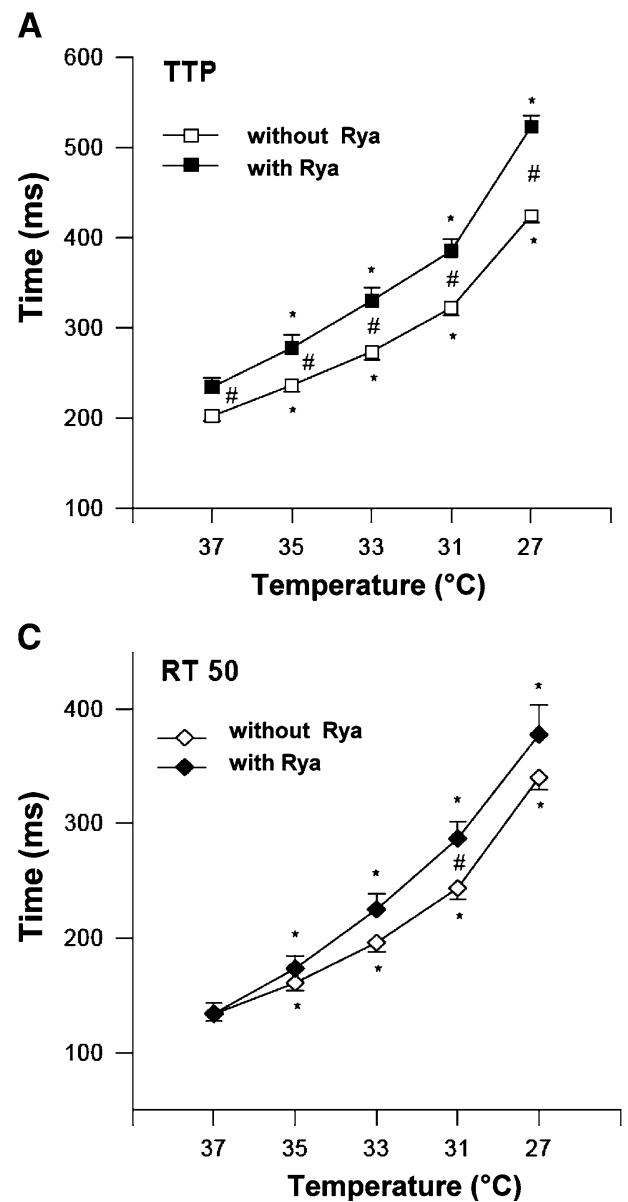
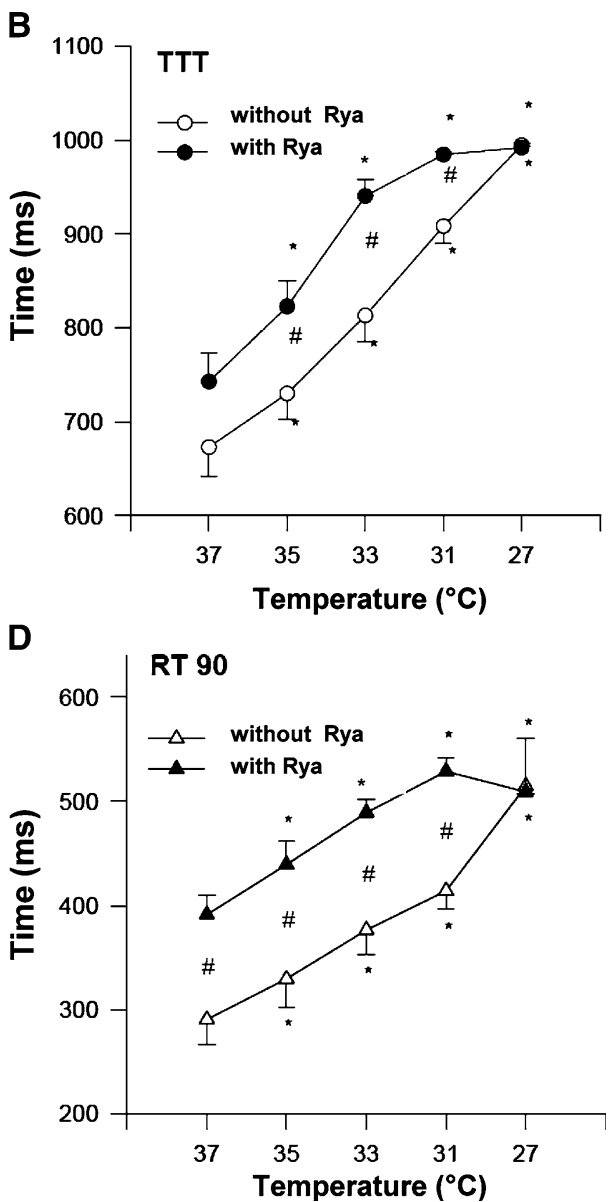

resistance (SVR) was significantly increased in these patients, which might explain the reduced cardiac output. In pigs mild hypothermia increased CI without significantly affecting SVR [16]. Higher incidence of required epinephrine infusions in the study of Bernard et al. [15] includes the rewarming period and does therefore not argue against our results.

To elucidate the subcellular effects of mild hypothermia, we performed RCC measurements in muscle strips from failing human myocardium. In contrast to previous data from pig myocardium [16], mild hypothermia moderately increased RCC amplitudes indicating that $\mathrm{SR} \mathrm{Ca}^{2+}$ content may be increased. One could speculate that increased SR $\mathrm{Ca}^{2+}$ load may be associated with subsequent enhanced $\mathrm{SR} \mathrm{Ca}^{2+}$ release. However, the inotropic response to hypothermia was still observed after complete blockade of SR function with ryanodine. This finding is in line with experimental data from Shattock and Bers [17], indicating that mechanisms, other than those involving the SR, contribute to the hypothermia-induced inotropism. One possibility is increased $\mathrm{Ca}^{2+}$ sensitivity. In the present study, hypothermia prolonged both contraction and relaxation times, indicating increased $\mathrm{Ca}^{2+}$ responsiveness of the myofilaments as an important underlying mechanism of positive inotropism [32]. Increased $\mathrm{Ca}^{2+}$ sensitivity might result from hypothermia-induced alkalosis [33, 34] or slowed cross-bridge cycling rate [35].

While systolic performance is clearly improved at all temperature steps investigated, increasing myofilament $\mathrm{Ca}^{2+}$ sensitivity might induce diastolic dysfunction [36]. In the present study, we observed an increase in diastolic force at $27^{\circ} \mathrm{C}$ particularly when SR function was inhibited by ryanodine, indicating that pronounced hypothermia might impair diastolic function. This has important implications for the treatment of successfully resuscitated patients, since diastolic dysfunction is a common phenomenon after ROSC [37-40]. However, in the temperature range recommended for therapeutic hypothermia in cardiac arrest patients $\left(32-34^{\circ} \mathrm{C}\right)[12,13]$, we did not observe any relevant changes in diastolic function. Furthermore, our clinical data demonstrate that hypothermia significantly reduces $\mathrm{HR}$, an intervention that usually improves LV filling [41]. However, since optimal cooling temperature is still under investigation, it should be considered that temperatures below the current 
recommendations might induce or worsen diastolic heart failure.

Post-cardiac arrest myocardial dysfunction is responsive to inotropic drugs $[39,42]$. In swine, dobutamine infusions of $5-10 \mu \mathrm{g}(\mathrm{kg} \mathrm{min})$ substantially improve systolic and diastolic function after cardiac arrest [39]. However, cAMP dependent inotropes such as $\beta$-adreno-agonists or phosphodiesterase III inhibitors, increase myocardial oxygen consumption, can exacerbate or induce ischemia in patients with coronary artery disease, can exert direct cardiac toxicity and have consistently been proven to increase mortality in chronic heart failure [43-45]. As discussed above, hypothermia most likely acts by sensitizing the myofilaments for $\mathrm{Ca}^{2+}$. In contrast to cAMP elevating inotropes, hypothermia prolongs contraction and relaxation times, acts partially independently of SR function and significantly reduces HR. Therefore, it may favorably impact myocardial energetics relative to traditional inotropic therapies. Animal studies have shown that in myocardial infarction hypothermia decreases oxygen consumption and infarct size [46, 47]. Preliminary data indicate that mild hypothermia might represent an attractive approach to increase contractility not only after cardiac arrest but also in other patients with cardiogenic shock [48].

Our clinical data demonstrate that hypothermia significantly reduces HR. In this context, it is important to note that the force-frequency relation is inversed during hypothermia. Lewis et al. [49] have nicely shown that higher HRs result in reduced contractility at colder temperatures. Therefore, lower HRs are beneficial during hypothermia.

This study has some limitations. Due to the hemodynamic stabilization during hypothermia induction, invasive hemodynamic measurements by pulmonary catheter were not performed routinely. Therefore, invasive hemodynamic data cannot be provided.

There was no normothermia control group of resuscitated patients with which to compare changes in hemodynamic parameters. Since post-cardiac arrest myocardial dysfunction is a potentially reversible phenomenon $[6,7$, 50], we cannot completely exclude that hemodynamic stabilization might occur independently of hypothermia induction. However, Bernard et al. [15] described no increase of CI values in the normothermia group during the first $6 \mathrm{~h}$ after admission to the ICU. Moreover, it has been reported that $\mathrm{CI}$ values reach their nadir at $8 \mathrm{~h}$ after resuscitation [6]. In contrast, we observed a significant reduction in epinephrine requirement within $6 \mathrm{~h}$, indicating an accelerated improvement of hemodynamics by induction of hypothermia. Furthermore, our in vitro experiments were performed in a control-matched setting, demonstrating that hypothermia instantly increases contractility in one and the same failing myocardial muscle strip.
During the re-warming period, the catecholamine doses were not changed significantly. However, the rewarming period could not be compared with the cooling induction for several reasons: (1) as mentioned above, post-cardiac arrest myocardial dysfunction reaches its nadir $8 \mathrm{~h}$ after ROSC. Contractility is known to recover after $24 \mathrm{~h} \mathrm{[6].} \mathrm{Therefore,} \mathrm{it} \mathrm{is} \mathrm{not} \mathrm{surprising} \mathrm{that} \mathrm{the}$ requirement for epinephrine and dobutamine did not rise again. (2) As recommended [12], hypothermia was induced as rapid as possible, whereas re-warming was performed very slowly $\left(0.2^{\circ} \mathrm{C} / \mathrm{h}\right)$. A body temperature of $36.5^{\circ} \mathrm{C}$ was reached after $18.7 \mathrm{~h}$ (almost 3 times slower than cooling induction). This is a long time for compensatory mechanisms. (3) Induction and maintenance of therapeutic hypothermia were performed under constantly deep sedation. During the re-warming period sedation was stopped after reaching $35^{\circ} \mathrm{C}$. Increasing vigilance will likely interfere with the need for catecholamines. (4) Normothermia was reached approximately $48 \mathrm{~h}$ after ROSC. At this time point many of the ventilated cardiac arrest patients are affected by infections and sepsis that will influence the hemodynamic situation.

Hemodynamic instability as part of the post-cardiac arrest syndrome is not only caused by myocardial dysfunction, but also a severe systemic ischemia/reperfusion response, having many characteristics in common with sepsis, i.e. systemic inflammation, endothelial activation, impaired vasoregulation and intravascular volume depletion [12, 51-54]. In the present study, we demonstrate that mild hypothermia increases contractility in failing human myocardium. This effect most likely contributes to the early hemodynamic stabilization we observed in cardiac arrest survivors treated with hypothermia. However, since hypothermia has been reported to increase SVR [15], this might also help to stabilize the hemodynamic situation in the post-cardiac arrest syndrome. In our study population the application rate of the vasopressor norepinephrine was slightly but not significantly increased during hypothermia induction and re-warming.

In conclusion, mild hypothermia stabilizes hemodynamics in cardiac arrest survivors, which might contribute to improved survival rates in these patients. As one possible mechanism we demonstrate that hypothermia increases contractility in the failing human myocardium most likely by increasing $\mathrm{Ca}^{2+}$ sensitivity. Further studies are required to evaluate hypothermia as inotropic intervention in patients with cardiogenic shock.

Acknowledgments Dr. Maier is funded by the Deutsche Forschungsgemeinschaft (DFG) through grants for a Clinical Research group KFO155 (MA 1982/2-2) and a Heisenberg grant (MA 1982/4-1), as well as by the Deutsche Gesellschaft für Kardiologie (DGK) by a Hengstberger grant. 
Conflict of interest statement The authors declare that they have no conflicts of interest.

Open Access This article is distributed under the terms of the Creative Commons Attribution Noncommercial License which permits any noncommercial use, distribution, and reproduction in any medium, provided the original author(s) and source are credited.

\section{References}

1. Fredriksson M, Herlitz J, Nichol G (2003) Variation in outcome in studies of out-of-hospital cardiac arrest: a review of studies conforming to the Utstein guidelines. Am J Emerg Med 21:276281

2. Nichol G, Thomas E, Callaway CW, Hedges J, Powell JL, Aufderheide TP, Rea T, Lowe R, Brown T, Dreyer J, Davis D, Idris A, Stiell I (2008) Regional variation in out-of-hospital cardiac arrest incidence and outcome. JAMA 300:1423-1431

3. Ehlenbach WJ, Barnato AE, Curtis JR, Kreuter W, Koepsell TD, Deyo RA, Stapleton RD (2009) Epidemiologic study of in-hospital cardiopulmonary resuscitation in the elderly. N Engl J Med 361:22-31

4. Nadkarni VM, Larkin GL, Peberdy MA, Carey SM, Kaye W, Mancini ME, Nichol G, Lane-Truitt T, Potts J, Ornato JP, Berg RA, for the National Registry of Cardiopulmonary Resuscitation Investigators (2006) First documented rhythm and clinical outcome from in-hospital cardiac arrest among children and adults. JAMA 295:50-57

5. Gazmuri RJ, Weil MH, Bisera J, Tang W, Fukui M, McKee D (1996) Myocardial dysfunction after successful resuscitation from cardiac arrest. Crit Care Med 24:992-1000

6. Laurent I, Monchi M, Chiche JD, Joly LM, Spaulding C, Bourgeois B, Cariou A, Rozenberg A, Carli P, Weber S, Dhainaut JF (2002) Reversible myocardial dysfunction in survivors of out-ofhospital cardiac arrest. J Am Coll Cardiol 40:2110-2116

7. Ruiz-Bailen M, de guayo HE, Ruiz-Navarro S, az-Castellanos MA, Rucabado-Aguilar L, Gomez-Jimenez FJ, Martinez-Escobar S, Moreno RM, Fierro-Roson J (2005) Reversible myocardial dysfunction after cardiopulmonary resuscitation. Resuscitation 66:175-181

8. Herlitz J, Ekstrom L, Wennerblom B, Axelsson A, Bang A, Holmberg S (1995) Hospital mortality after out-of-hospital cardiac arrest among patients found in ventricular fibrillation. Resuscitation 29:11-21

9. Laver S, Farrow C, Turner D, Nolan J (2004) Mode of death after admission to an intensive care unit following cardiac arrest. Intensive Care Med 30:2126-2128

10. The Hypothermia after Cardiac Arrest Study Group (2002) Mild therapeutic hypothermia to improve the neurologic outcome after cardiac arrest. N Engl J Med 346:549-556

11. Holzer M, Bernard SA, Hachimi-Idrissi S, Roine RO, Sterz F, Mullner M (2005) Hypothermia for neuroprotection after cardiac arrest: systematic review and individual patient data meta-analysis. Crit Care Med 33:414-418

12. Neumar RW, Nolan JP, Adrie C, Aibiki M, Berg RA, Bottiger BW, Callaway C, Clark RSB, Geocadin RG, Jauch EC, Kern KB, Laurent I, Longstreth WT Jr, Merchant RM, Morley P, Morrison LJ, Nadkarni V, Peberdy MA, Rivers EP, Rodriguez-Nunez A, Sellke FW, Spaulding C, Sunde K, Vanden Hoek T (2008) PostCardiac Arrest Syndrome: Epidemiology, Pathophysiology, Treatment, and Prognostication A Consensus Statement From the International Liaison Committee on Resuscitation (American
Heart Association, Australian and New Zealand Council on Resuscitation, European Resuscitation Council, Heart and Stroke Foundation of Canada, InterAmerican Heart Foundation, Resuscitation Council of Asia, and the Resuscitation Council of Southern Africa); the American Heart Association Emergency Cardiovascular Care Committee; the Council on Cardiovascular Surgery and Anesthesia; the Council on Cardiopulmonary, Perioperative, and Critical Care; the Council on Clinical Cardiology; and the Stroke Council. Circulation 118:2452-2483

13. International Liaison Committee on Resuscitation (2005) Proceedings of the 2005 international consensus on cardiopulmonary resuscitation and emergency cardiovascular care science with treatment recommendations. Resuscitation 67:157-341

14. Storm C, Schefold JC, Kerner T, Schmidbauer W, Gloza J, Krueger A, Jorres A, Hasper D (2008) Prehospital cooling with hypothermia caps (PreCoCa): a feasibility study. Clin Res Cardiol 97:768-772

15. Bernard SA, Gray TW, Buist MD, Jones BM, Silvester W, Gutteridge G, Smith K (2002) Treatment of comatose survivors of out-of-hospital cardiac arrest with induced hypothermia. N Engl J Med 346:557-563

16. Weisser J, Martin J, Bisping E, Maier LS, Beyersdorf F, Hasenfuss G, Pieske B (2001) Influence of mild hypothermia on myocardial contractility and circulatory function. Basic Res Cardiol 96:198-205

17. Shattock MJ, Bers DM (1987) Inotropic response to hypothermia and the temperature-dependence of ryanodine action in isolated rabbit and rat ventricular muscle: implications for excitationcontraction coupling. Circ Res 61:761-771

18. Langendorff O (1897) Untersuchungen am überlebenden Säugetierherzen. Über den Einfluss von Wärme und Kälte auf das Herz der warmblütigen Tiere. Pflugers Arch 355-400

19. Sprung J, Stowe DF, Kampine JP, Bosnjak ZJ (1994) Hypothermia modifies anesthetic effect on contractile force and $\mathrm{Ca} 2+$ transients in cardiac Purkinje fibers. Am J Physiol 267:H725$\mathrm{H} 733$

20. Goetzenich A, Schroth SC, Emmig U, Autschbach R, Pieske B, Rossaint R, Christiansen S (2009) Hypothermia exerts negative inotropy in human atrial preparations: in vitro-comparison to rabbit myocardium. J Cardiovasc Surg (Torino) 50:239-245

21. Herren T, Gerber PA, Duru F (2009) Arrhythmogenic right ventricular cardiomyopathy/dysplasia: a not so rare "disease of the desmosome" with multiple clinical presentations. Clin Res Cardiol 98:141-158

22. Nalenz C, Konradi D, Blank R, Rupprecht HJ (2007) 58-year-old patient with cardiac arrest due to coronary spasm. Clin Res Cardiol 96:824-828

23. Strauss M, Gitt AK, Becker T, Kleemann T, Schiele R, Darius H, Junger C, Senges J, Seidl K (2008) Prehospital cardiac arrest: a marker for higher mortality in patients with acute myocardial infarction and moderately reduced left ventricular function: results from the MITRA plus registry. Clin Res Cardiol 97:748752

24. Jung C, Ferrari M, Rodiger C, Fritzenwanger M, Figulla HR (2008) Combined impella and intra-aortic balloon pump support to improve macro- and microcirculation: a clinical case. Clin Res Cardiol 97:849-850

25. Lam K, Sjauw KD, Henriques JP, Ince C, de Mol BA (2009) Improved microcirculation in patients with an acute ST-elevation myocardial infarction treated with the Impella LP2.5 percutaneous left ventricular assist device. Clin Res Cardiol 98:311-318

26. Jung C, Rodiger C, Fritzenwanger M, Schumm J, Lauten A, Figulla HR, Ferrari M (2009) Acute microflow changes after stop and restart of intra-aortic balloon pump in cardiogenic shock. Clin Res Cardiol 98:469-475 
27. Pieske B, Maier LS, Bers DM, Hasenfuss G (1999) Ca2+ handling and sarcoplasmic reticulum $\mathrm{Ca} 2+$ content in isolated failing and nonfailing human myocardium. Circ Res 85:38-46

28. Sossalla S, Wagner S, Rasenack ECL, Ruff H, Weber SL, Schöndube FA, Tirilomis T, Tenderich G, Hasenfuss G, Belardinelli L, Maier LS (2008) Ranolazine improves diastolic dysfunction in isolated myocardium from failing human hearts-role of late sodium current and intracellular ion accumulation. J Mol Cell Cardiol 45:32-43

29. Mulieri LA, Hasenfuss G, Ittleman F, Blanchard EM, Alpert NR (1989) Protection of human left ventricular myocardium from cutting injury with 2, 3-butanedione monoxime. Circ Res 65:1441-1449

30. Hasenfuss G, Pieske B (2002) Calcium cycling in congestive heart failure. J Mol Cell Cardiol 34:951-969

31. Hasenfuss G, Reinecke H, Studer R, Meyer M, Pieske B, Holtz J, Holubarsch C, Posival H, Just H, Drexler H (1994) Relation between myocardial function and expression of sarcoplasmic reticulum $\mathrm{Ca}(2+)$-ATPase in failing and nonfailing human myocardium. Circ Res 75:434-442

32. Blinks JR, Endoh M (1986) Modification of myofibrillar responsiveness to $\mathrm{Ca}++$ as an inotropic mechanism. Circulation 73:III85-III98

33. Churcott CS, Moyes CD, Bressler BH, Baldwin KM, Tibbits GF (1994) Temperature and $\mathrm{pH}$ effects on $\mathrm{Ca} 2+$ sensitivity of cardiac myofibrils: a comparison of trout with mammals. Am J Physiol 267:R62-R70

34. Fabiato A, Fabiato F (1978) Effects of $\mathrm{pH}$ on the myofilaments and the sarcoplasmic reticulum of skinned cells from cardiac and skeletal muscles. J Physiol 276:233-255

35. Henderson AH, Cattell MR (1976) Length-induced changes in activation during contraction. A study of mechanical oscillations in strontium-mediated contractions of cat and frog heart muscle. Circ Res 38:289-296

36. Abraham TP, Jones M, Kazmierczak K, Liang HY, Pinheiro AC, Wagg CS, Lopaschuk GD, Szczesna-Cordary D (2009) Diastolic dysfunction in familial hypertrophic cardiomyopathy transgenic model mice. Cardiovasc Res 82:84-92

37. Kern KB, Berg RA, Hilwig RW, Larson DF, Gaballa MA (2008) Myocardial cytokine IL-8 and nitric oxide synthase activity during and after resuscitation: preliminary observations in regards to post-resuscitation myocardial dysfunction. Resuscitation 77:401-409

38. McCaul CL, McNamara P, Engelberts D, Slorach C, Hornberger LK, Kavanagh BP (2006) The effect of global hypoxia on myocardial function after successful cardiopulmonary resuscitation in a laboratory model. Resuscitation 68:267-275

39. Kern KB, Hilwig RW, Berg RA, Rhee KH, Sanders AB, Otto CW, Ewy GA (1997) Postresuscitation left ventricular systolic and diastolic dysfunction: treatment with dobutamine. Circulation 95:2610-2613

40. Hettwer S, Panzner-Grote B, Witthaut R, Werdan K (2007) Isolated diastolic dysfunction-diagnostic value of tissue Doppler imaging, colour M-mode and N-terminal pro B-type natriuretic peptide. Clin Res Cardiol 96:874-882

41. Reil JC, Bohm M (2007) The role of heart rate in the development of cardiovascular disease. Clin Res Cardiol 96:585-592

42. Huang L, Weil MH, Tang W, Sun S, Wang J (2005) Comparison between dobutamine and levosimendan for management of postresuscitation myocardial dysfunction. Crit Care Med 33:487-491

43. Felker GM, O'Connor CM (2001) Inotropic therapy for heart failure: an evidence-based approach. Am Heart J 142:393-401

44. Packer M, Carver JR, Rodeheffer RJ, Ivanhoe RJ, DiBianco R, Zeldis SM, Hendrix GH, Bommer WJ, Elkayam U, Kukin ML (1991) Effect of oral milrinone on mortality in severe chronic heart failure. The PROMISE Study Research Group. N Engl J Med 325:1468-1475

45. Overgaard CB, Dzavik V (2008) Inotropes and vasopressors: review of physiology and clinical use in cardiovascular disease. Circulation 118:1047-1056

46. Miki T, Liu GS, Cohen MV, Downey JM (1998) Mild hypothermia reduces infarct size in the beating rabbit heart: a practical intervention for acute myocardial infarction? Basic Res Cardiol 93:372-383

47. Kuhn LA, Apter R, Weinrauch H, Jacobson TE, Meltzer L (1963) Hemodynamic and metabolic effects of skin and blood-stream cooling in experimental myocardial infarction with shock. Am J Cardiol 12:795-801

48. Schmidt-Schweda S, Ohler A, Grothe A, Pieske B (2004) Mild hypothermia in cardiogenic shock (COOL-SHOCK). Eur Heart J 25(Suppl 1):653-654

49. Lewis ME, Al-Khalidi AH, Townend JN, Coote J, Bonser RS (2002) The effects of hypothermia on human left ventricular contractile function during cardiac surgery. J Am Coll Cardiol 39:102-108

50. Vasquez A, Kern KB, Hilwig RW, Heidenreich J, Berg RA, Ewy GA (2004) Optimal dosing of dobutamine for treating postresuscitation left ventricular dysfunction. Resuscitation 61:199207

51. Adrie C, dib-Conquy M, Laurent I, Monchi M, Vinsonneau C, Fitting C, Fraisse F, nh-Xuan AT, Carli P, Spaulding C, Dhainaut JF, Cavaillon JM (2002) Successful cardiopulmonary resuscitation after cardiac arrest as a "sepsis-like" syndrome. Circulation 106:562-568

52. Karimova A, Pinsky DJ (2001) The endothelial response to oxygen deprivation: biology and clinical implications. Intensive Care Med 27:19-31

53. Debrunner M, Schuiki E, Minder E, Straumann E, Naegeli B, Mury R, Bertel O, Frielingsdorf J (2008) Proinflammatory cytokines in acute myocardial infarction with and without cardiogenic shock. Clin Res Cardiol 97:298-305

54. Reinhart K, Brunkhorst FM, Bone HG, Gerlach H, Grundling M, Kreymann G, Kujath P, Marggraf G, Mayer K, Meier-Hellmann A, Peckelsen C, Putensen C, Stuber F, Quintel M, Ragaller M, Rossaint R, Weiler N, Welte T, Werdan K (2006) Diagnosis and therapy of sepsis. Clin Res Cardiol 95:429-454 